\title{
A Critical Survey of Cusanus's Writings on Islam
}

\author{
Walter Andreas Euler
}

Cusanus authored three writings mainly dealing with Islam: De pace fidei, dating from September 1453, the letter addressed to John of Segovia from December 29, 1454, and Cribratio Alkorani, 1460/61. All three of these writings date from the second period of his career, after he had been appointed cardinal and bishop.

Yet Nicholas of Cusa had shown interest in Islam long before that. In his first preface to Cribratio Alkorani, Nicholas invokes his earlier endeavors to gain an understanding of Islam, referring to the Council of Basel, where he had been active from 1432 to 1437, and his journey to Constantinople in 1437. He claims to have acquired the Latin translation of the Qur'an by Robert of Ketton in Basel, and to have gone to Constantinople to search for further copies of the Quran. He stresses that Franciscan friars showed him an Arabic Qur'an there. ${ }^{1}$ Hence, if we want to believe him - and there is no reason to do otherwiseNicholas had already been studying the Qur'an for 17-20 years by the time he wrote De pace fidei. "I have always sought, with all that is in my power, to

1 Prol. I, Opera omnia Nicolai de Cusa (= h) VIII, n. 2: "As best I could, I made a careful attempt to understand the book-of-law of the Arabs- [a book] which I obtained at Basel in the translation commissioned for us by Peter, Abbot of Cluny. [I obtained it] together with a debate among those noble Arabs, [wherein] one of them, a follower of Muhammad, attempted to win over another of them - who, being eminent among the Arabs and quite learned, showed that the Christian faith, which he zealously observed, ought rather to be accepted. There were also [contained therein] certain other works on the origins of Muhammad, his twelve successors in the kingdom, and on his Doctrinae ad centum questiones. I left the book with Master John of Segovia and journeyed to Constantinople, where among the Minorites who were living at [the Church of] the Holy Cross, I found the Koran in Arabic. These brothers, as best they knew how, explained it to me in regard to certain of its points. But in Pera, at the Convent of St. Dominicus, [I found a copy of the Koran that] was translated in the [same] manner as [the one] I had left behind in Basel. I inquired whether any of the Greeks had written against these foolish errors. And I learned only that John of Damascus, who lived a little after the beginning of that sect, had written the very few things which were on hand there." Translated in Jasper Hopkins, Nicholas of Cusa's De pace fidei and Cribratio Alkorani: Translation and Analysis (Minneapolis: Arthur J. Banning Press, 1990), 75. Hereafter cited as Hopkins, Cusa's De pace fidei and Cribratio. 
understand the book of the law of the Arabs (= Qur'an)," says Cusanus in the opening pages of his Cribratio. ${ }^{2}$

Furthermore, alongside his Latin version of the Qur'an, translated by Robert of Ketton by order of Petrus Venerabilis in 1143 (Cod. Cus. 108 in the library of the St. Nicholas Hospital in Bernkastel-Kues), Cusanus might have also been in the possession of the Arabic original. The St. Nicholas Hospital disposed of an Arabic Quran that was sold in $1823 / 24 \cdot^{3}$

The American scholar James E. Biechler has written a remarkable essay entitled "Three Manuscripts on Islam from the library of Nicholas of Cusa," analyzing in detail the marginal notes in the Latin Quran of Nicholas of Cusa. Judging from the changes in his writing, Biechler comes to the conclusion that Cusanus must have studied the Qur'an thoroughly at least three times in his life: at the time of the Council of Basel in the first half of the 1430s, at the time of the composition of De pace fidei, and finally, when he was writing Cribratio Alkorani.

\section{De pace fidei: An Inclusive Approach to Islam}

Let us first take a look at De pace fidei. Nicholas's well-known plea, expressed in the introduction, sounds peculiar, a little bit wan and feeble against the tragic historical background of the conquest of Constantinople by the Turks. He writes: May God stop the horribly widespread persecution caused by religious differences, "ob diversum ritum religionum." ${ }^{5}$ One would normally expect a cardinal and bishop of the fifteenth century to explicitly name the responsible people and to formulate his plea in a correspondingly glaring way, for example:

May God stop the Muslim Turks and punish them with all his might for their crimes against the poor Byzantine Christians, although they themselves are more or less to blame for their fate. Therefore, they deserve a certain kind of chastisement because they have disgracefully broken off

2 Hopkins, Cusa's De pace fidei and Cribratio, 75.

3 See the discussion by Hermann J. Hallauer concerning the paper of Anton Schall: "Die Sichtung des Christlichen im Koran," Mitteilungen und Forschungsbeiträge der CusanusGesellschaft 9 (1971): 89 .

4 This article was published in the periodical Manuscripta 27 (1983): 91-100.

5 De pace fidei, ch. 1, h VII, 3, lines 3-8: "Fuit ex hiis, quae apud Constantinopolim proxime saevissime acta per Turkorum regem divulgabantur, quidam vir zelo Dei accensus, qui loca illarum regionum aliquando viderat, ut pluribus gemitibus oraret omnium creatorem quod persecutionem, quae ob diversum ritum religionum plus solito saevit, sua pietate moderaretur." 
the union with the Latins, but their guilt is by far less severe than that of the Turks.

All this is analogously expressed in the sermon that the cardinal and princebishop Nicholas of Cusa delivered in Neustift, near Brixen, on August 24, 1456. It is sermon CCXL. ${ }^{6}$ The occasion was a procession to celebrate the victory over the Turks near Belgrade on July 22, 1456. In that sermon, Cusanus calls the Turks a scourge, a flagellum - an image also found in his letter to John of Segovia from December 29, $1454^{7}$ — which is meant to wake up the somnolent Christians. And he adds:

God will prove to be the loyal guardian of us Christians if we, filled with faith, seek refuge in him, knowing that we will undoubtedly be saved ${ }^{8}$ if we trust in his protection, willingly and with all our heart. ${ }^{9}$

The reason Nicholas does not express any anti-Islamic ideas or announce an intellectual crusade plan in the introduction of De pace fidei, contrary to Sermon CCXL, is very simple. Islam, the religion of those who have invaded and conquered Constantinople, was meant to be integrated into the concordance of religions, which the cardinal became aware of after long days of contemplation. Thus, his argumentation in the introduction is already quite revealing. It shows 'in nuce' the theological conception concerning Islam that would develop throughout the work. All further explanations confirm that first impression. It becomes clear that Cusanus does not consider Islam to be hopelessly corrupted, anti-Christian, and demoniacal, but instead finds that it contains a true and sane core that needs to be carefully exposed first. His

6 Sermo CCXL, h XIX, n. 3-4.

7 Epistola ad Ioannem de Segobia, h VII, 100, lines 16-25: "Nam pluries tepiditate Ecclesiam subintrante excitata sunt flagella. Venerunt Romam aliquando Sarraceni et Ecclesiam sancti Petri depraederunt; excitata dormiens Ecclesia ad Dominum habuit refugium. Odit Deus tepiditatem, quia Deus zelotes. Unde, si occasiones tollerentur quare contra nos sed pro nostra salute et decore Ecclesiae Christus ista permittit, esset infallibile remedium. Ego firmissime credo non ad mortem sed vitam, non ad suppressionem sed exaltationem fidei persecutionem permitti. Ecclesia hoc proprium habet quod sub persecutione splendescit."

8 Here, Nicholas alludes not only to the eternal salvation, but also to the rescue from the threat of the Turks.

9 Sermo CCXL, h XIX, n. 5: "Haec est dies boni nuntii, in quo recepimus plures litteras huius miraculosae victoriae. Quapropter convenimus, ut laudemus Deum, qui mirabili ordine memoriam crucis renovavit, agente hoc per flagellum, quo somnolenti excitaremur ac quod invocemus eum, qui ostendit se pium protectorem, quando tota fide ad ipsum recurrimus, scientes quia indubie salvi erimus, si ex toto corde nos suae tuitione commendaverimus." 
program could be described as 'inclusion instead of exclusion'-inclusion and pro-Christian interpretation instead of exclusion and condemnation. Nicholas of Cusa consistently pursues this approach in his writing about peace in faith. Therefore, throughout his work there is not a single sentence, not a single thought condemning Islam as a fundamentally anti-Christian religious system.

How does this inclusion of Islam into the concept of De pace fidei work in detail? Cusanus simply calls the Muslims 'Arabs'-in Latin, 'arabes.' Every time that key term occurs, Nicholas invokes genuine Islamic concepts, which he seeks to link with his Christian views, the foundation of 'una religio,' the only true religion. The substance of the topics he thereby invokes can also be found in his letter to John of Segovia from December $29,1454{ }^{10}$ Moreover, Cusanus' argumentation is maieutic and manuductory. Maieutics is the art of midwifery attributed to Socrates in Plato's dialogues, allowing his interlocutors to gain insight into the philosophy step by step. 'Manuductio,' hand guidance, is a term used by Nicholas of Cusa in his Cribratio Alkorani. ${ }^{11}$ It implies that all non-Christians, Muslims in particular, should be taken by the hand to introduce them to the Christian faith.

In chapter IX of De pace fidei, Cusanus points out that fertility is a part of God's nature. ${ }^{12}$ He explains that perfection and divinity do not remain isolated; they are not sterile but procreate, because God-equally in accordance with the opinions expressed in the Qur'an ${ }^{13}$ —is spirit, rationality, and will. That is love in the Christian understanding. God as a spirit is aware of himself and therefore actively conceives the concept, the word of himself. The connection of both begets the will that originates from self-awareness.

According to Nicholas of Cusa, this insight is adequately represented by the Christian doctrine of the holy trinity, which in itself preserves the principle of divine unity. He is convinced that the criticism of the dogma of trinity expressed by Jews and Muslims is nothing but a misunderstanding, where the concept of the divine trinity is misinterpreted to be a tritheism, a belief in three Gods, and hence a variation of polytheism. In reality, however, Christians, Jews, and Muslims agree in this point, as all of them value the one and only true God as constructive force. Consequently, the quarrel is superfluous and senseless,

10 Cf. h VII, 97, lines 22-100, line 10.

11 The term 'manuductio' can be found in the second book of Cribratio Alkorani in the headings of chapters $5^{-7}$ and 10, which treat different aspects of the theology of the holy trinity; cf. h VIII, n. 99: "Manuductio ex his quae in mundo sunt, ut videatur deus trinus"; n. 101: "Manuductio de intellectuali trinitate ad divinam"; n. 103: "Manuductio eiusdem per amorem"; n. 111: "Iterum ex tribus personis manuductio."

12 Cf. h VII, 26, lines 11-28, line 4.

13 Cusanus refers to Sura 4:171, among others. 
caused by terms that generate different meanings. Furthermore, technically speaking Jews as well as Muslims do already believe in the holy trinity without being aware of it.

Concerning the hypostatic union of God and man in the person of Christ, Nicholas of Cusa not only aims at elucidating misunderstandings as to the use of the term, as he did with the concept of the holy trinity. Rather, he tries to dig deeper, in order to find a Christian foundation in the Qur'an. ${ }^{14}$ This 'crypto-Christian' factor is constituted by appreciative statements the Qur'an makes about Jesus the Islamic prophet, as found in Cusanus's Latin translation of the Qur'an. Such statements include: he was born by the Virgin Mary (Sura 3:47 and 19:20); he could work marvellous miracles, for instance raising the dead and making birds out of clay (Sura 3:49 and 5:110); he was the Messiah, the word and the spirit of God (Sura 4:171, among others); and finally, he was the face of all peoples and the highest being in the world. ${ }^{15}$ With exception of the last two notions, Jesus as 'the face of all peoples' and the highest being in the world, which were mistranslations in the Latin version of the Qur'an used by Cusanus, ${ }^{16}$ all other statements are authentic. Yet, though they can indeed be found in the Quran, they cannot always be interpreted from a Christian point of view. ${ }^{17}$

Nicholas of Cusa considers these statements about Jesus as maximal statements, setting the Nazarene apart from all other humans. Cusanus extensively develops this approach in his oeuvre De docta ignorantia (1440). In the first three chapters of the third book, he speculatively develops the idea that the highest individual of a species necessarily exceeds the limitations of the species. Applied to the human being as the highest of creatures, this means that the highest human is more than a mere human-he is God. Already in De docta ignorantia this consideration serves to explain and highlight the hypostatic union in Christ, without referring to the Holy Scripture. ${ }^{18}$ He then transfers this to the dialogue with Islam in De pace fidei as follows: if the Qur'an uses 'maximal' statements about Jesus of Nazareth, these statements imply that Jesus was more than a saint, more than an exceptionally gifted man through the grace of God, and that he must therefore be intimately joined to the divine nature. Cusanus frequently illustrates this point with the image of human nature as

\footnotetext{
14 Cf. h VII, 37, lines 9-39, line 15.

15 Cf. ch. 13 of De pace fidei, h VII, 40, lines 15-16: "facies omnium gentium et altissimus."

16 Cf. Adnotatio 24: h VII, 80.

17 Cf. inter alia, Claus Schedl, Muhammad und Jesus. Die christologisch relevanten Texte des Korans (Vienna: Herder, 1978).

18 Cf. Rudolf Haubst, Die Christologie des Nikolaus von Kues (Freiburg: Herder, 1956), 143-172.
} 
iron being pulled up by the divine magnet. Hence, in Christian terms, Jesus can be considered the son of God.

The cardinal does not say that the Qur'an teaches the hypostatic union in the person of Christ, but that the Muslims are 'facilius,' or more easily converted to the Christian faith, because the Qur'an gives clear hints that have just been neglected by the Muslims thus far. Nicholas of Cusa, as Christian interpreter of the Qur'an, discloses the hermeneutical key to the decryption of the Quran, without forgetting the Muslims' fear that the notion of Christ being the son of God may threaten the divine unity.

Chapter XIV of De pace fidei treats the death of Christ on the cross. ${ }^{19}$ From his Latin translation of the Qur'an, Cusanus was well aware that it categorically denies the crucifixion of Christ (Sura 4:157), though he realized the denial is meant to do Jesus honor ('ad reverentiam'). This aspect is of crucial importance for his argumentation. Cusanus ardently seeks to show that the 'mors turpissima crucis' (the ignominious death on the cross) only harmed Christ's honor at a first glance because the Muslims believe that such a death is not worthy of a true prophet. In fact, this makes it evidently clear that Jesus was only bound to God in truth and allegiance, and therefore deserves to be honored as the highest of all men. ${ }^{20}$ Furthermore, this shows that by taking a closer look at the 'gloria crucis,' or the glory of the cross, Muslims will come to acknowledge and respect it too. Cusanus's thoughts on the subject can be summarised as follows: the Muslims are doubtlessly wrong in denying the death of Jesus on the cross, but - and here the notion of inclusion becomes obvious - they are wrong because of good motives, because they want to pay honor to Jesus of Nazareth. Thus, Nicholas believes that their mistake can be reversed.

In sermon CCXL, Nicholas of Cusa identifies the vision of paradise in the Qur'an as the element of complete reversal of the message of the Gospel, done by the devil—with Mohammed working as his tool—to seduce primitive, animalistic humans. ${ }^{21}$ Thus, the sermon claims that the vision of paradise in the Quran proves two things: it exposes the hand of the devil, as well as the intellectual inferiority of the Muslims. In chapter XV of De pace fidei, however, Cusanus introduces Mohammed as an intelligent pedagogue of the people, who succeeds in dissuading his addressees from polytheism

19 Cf. h VII, 44, lines 4-46, line 7.

20 Cf. Walter Andreas Euler, "Does Nicholas Cusanus Have a Theology of the Cross?," The Journal of Religion 80 (2000): 405-420; Euler, "Oboedire est vivere: Obedience and Freedom According to the Brixen Sermons of Nicholas of Cusa," in Nicholas of Cusa on the Self and Self-Consciousness, ed. Walter Andreas Euler, Ylva Gustafsson and Iris Wikström (ÅboTurku: Åbo Akademi University Press, 2010), 25-38. 
by evoking a land of milk and honey in his vision of paradise. ${ }^{22}$ Hence, Cusanus manages an inclusion of Islam by implying - similar to the Islamic philosopher Avicenna — that the Qur'an says something different from what it explicitly states.

\section{Cusanus and Segovia: Questioning Inclusion}

I have tried to characterize the theological approach of Nicholas of Cusa in De pace fidei regarding Islam by highlighting the notion of inclusion. This notion, however, leads to many questions. It can be seen as a legitimate inclusion of Islam or a sort of integration, but it can also be perceived as a problematic interpretation inspired by specifically Christian values that are alien, sometimes even contrary, to those of Islam.

After a while, Cusanus himself realised that his pro-Christian, inclusive interpretation entangles Islam in a certain one-sided interpretation. However, it is unknown as to when he came to this awareness. I suspect that he was still absolutely convinced that the Quran could be interpreted in a cryptoChristian way at the time he was writing De pace fidei. Nonetheless, it becomes obvious from an interesting remark in his letter to John of Segovia from December 29, 1454, that he had experienced a change of mind in the fifteen months that lay between De pace fidei and that letter.

The critical attitude of John of Segovia concerning Islam, expressed in his letter to Cusanus on December 2, 1454, might be a reason for this change. Concerning the content, Cusanus's argumentation in the letter to John of Segovia is still absolutely in line with the ideas of De pace fidei. Not without reason does Nicholas of Cusa point to that work, stating that he would send the book to the Spanish scholar once a copy became available. ${ }^{23}$ Yet, the following statement can be found after some considerations concerning the Islamic vision of paradise:

It seems as if we are obliged to keep trying to interpret that book [the Quran], so important to them, as being commissioned for our sake. For we find things in it that are useful to us; and we will interpret all the others which are contrary through the first ones. ${ }^{24}$

\footnotetext{
22 Cf. h VII, 47, lines 5-5o, line 2.

23 Cf. Epistola, h VII, 97, lines 2-4.

24 Epistola, h VII, 99, lines 22-25: "Unde videtur quod semper ad hoc conandum sit quod liber iste, qui apud eos est in auctoritate, pro nobis allegetur. Nam reperimus in eo talia quae serviunt nobis; et alia quae contrariantur, glosabimus per illa."
} 
This statement is the first literary proof that Cusanus had become aware of the Qur'an's ambivalence concerning the Christian faith. Nevertheless, he remains convinced that the pro-Christian essence of the Quran is far more substantial than the conflicting elements, and that a corresponding interpretation of Islam is therefore hermeneutically valid.

\section{Cribratio Alkorani and the Ambivalence of Islam}

Much happened during the years between the letter to John of Segovia and the composition of Cribratio Alkorani. According to Sermo CCXL, the victory over the Turks near Belgrade in the summer of 1456 seems to have raised Cusanus's hope that the expansion of Islam might be stopped and that, with God's help, everything would turn out fine for Christendom. That short moment of euphoria, however, did not last long. The sermon makes clear that Nicholas of Cusa supported the military resistance to the expansion of the Turks. He considered it as a legitimate resistance and not as an aggression, contradictory to Christ's commandment, as he points out in his letter to John of Segovia. ${ }^{25}$

Cribratio Alkorani, an utterly complex and manifold opus, is one of the most important works of Nicholas of Cusa in the last years of his life. Contrary to De pace fidei, Cribratio Alkorani does not show a clear goal in its discussion with Islam. Although the inclusive, pro-Christian interpretation of Islam is extensively represented, it is consistently thwarted by anti-Christian interpretations. Accordingly, Cusanus argues that due to 'pia interpretatione' (or pious, Christian interpretations), the Qur'an could be considered as a 'secret Gospel, ${ }^{26}$ yet it is the product of a debauchee who cared only for glory, might, and wealth. Following the older Christian apologetic, Cusanus claims that Mohammed died as a heretical Christian, ${ }^{27}$ and stresses that Mohammed's knowledge of

25 Epistola, h VII, 97, lines 5-11: "Assentio igitur rationibus vestris fundatissimis tam in iure divino quam humano; quia si iuxta doctrinam Christi processerimus, non errabimus, sed spiritus eius loquetur in nobis, cui non poterunt omnes adversarii Christi resistere; sed si invasionis gladio aggressionem eligerimus, formidare habemus ne gladio pugnantes gladio pereamus. Unde sola defensio sine periculo est Christiano."

26 Cusanus uses the phrase 'pia interpretatio' only in the second book of Cribratio Alkorani: II, 1 (h VIII, n. 86, lines 4-6); II, 12 (h VIII, n. 119, lines 1-2); II, 13 (h VIII, n. 124, lines 3-4); II, 19 (h VIII, n. 154, lines 8-9); cf. Tom Kerger, "Die cusanische Sichtung des Korans," in Cusanus und der Islam, ed. Walter Andreas Euler and Tom Kerger (Trier: Paulinus, 2010), 95-102.

27 Cf. Prol. II, h VIII, n. 11: "That noble Arab Christian whom I previously mentioned, reports the following: Sergius, a monk evicted from his monastery, journeyed to Mecca. There he found two groups of people, [viz.,] idolaters and Jews; and there he preached the 
the truth was contaminated by ignorance ('ignorantia') and perverse intentions ('perversitas intentionis'). ${ }^{28}$ Moreover, he contends that 'tres astutissimi Judaei' (three extremely sly Jews) had added anti-Christian amendments to the Qur'an, ${ }^{29}$ resulting in an even further alienation from Christianity.

Thus, in Cribratio Alkorani Cusanus considers the holy book of the Muslims to be a book containing contradictory tendencies with regard to its content, as well as a 'confusissimus liber' concerning its form. He regards the Qur'an as being a highly abstruse creation because every single chapter has to be analyzed separately, as the different Suras were not coherently connected with

Christian faith as Nestorius held it, [doing so] in order to regain favor with his [monastic] brothers, [who were also] of the sect of Nestorius. And he succeeded in converting all the idolaters to his own faith. Among these was Muhammad, who, having been converted from idolatry, died a Nestorian Christian. But three very clever Jews attached themselves to Muhammad in order to turn him aside, lest he become perfect; and they induced him to various evils. But after Muhammad's death, when all [the idolaters] returned to their own [respective] sect, these [three] Jews approached Alis—son of Abitalip—to whom Muhammad had sent his collection [of precepts], and persuaded him to elevate himself unto a prophet, even as Muhammad too [had elevated himself]. And with regard to Muhammad's book they added and deleted what they wanted to." Hopkins, Cusa's De pace fidei and Cribratio, 79.

28 Prol. I, h VIII, n. 9-10: "But Jesus, the son of the Virgin Mary and the Christ who was foretold by Moses and the Prophets to be coming, did come and did reveal most perfectly-according to the testimony even of Muhammad — the oft-mentioned way, for He was ignorant of nothing. Therefore, it is certain that anyone who follows Christ and His way will attain unto an understanding of the desired Good. Hence, if Muhammad in any respect disagrees with Christ, then it follows either that he does so out of ignorance, because he did not know Christ and did not understand Him, or that there is perverse intent, because he did not intend to lead men to that goal-of-rest to which Christ showed the way but rather sought his own glory under the guise of that goal. A comparison of the law of Christ with the law of Muhammad will teach [us] that both of these [alternatives] must be believed to be true. I believe that the following must be maintained: viz., that ignorance was the cause of [Muhammad's] error and malevolence. For no one who is acquainted with Christ disagrees with Him or detracts from Him. Now, my intention is as follows: having presupposed the Gospel of Christ, to analyze the book of Muhammad and to show that even in it there are contained those [teachings] through which the Gospel would be altogether confirmed, were it in need of confirmation, and that wherever [the Koran] disagrees [with Christ], this [disagreement] has resulted from Muhammad's ignorance and, following [thereupon], from his perverse intent. For whereas Christ sought not His own glory but the glory of God the Father and the salvation of men, Muhammad sought not the glory of God and the salvation of men but rather his own glory." Hopkins, Cusa's De pace fidei and Cribratio, 78-79.

29 Cf. Prol. II, h VIII, n. 11 (see note 27). 
each other. Nicholas of Cusa says forthrightly at the end of his second preface that he did not succeed in discerning a clear order in the Qur'an, and that was why his interpretations of the text were also rather confused..$^{30}$

With respect to the evaluation of Islam, Cribratio Alkorani ends with an odd result, which can be paraphrased as follows: the Qur'an exhibits 'inclusion and exclusion,' with pro- and anti-Christian assessments simultaneously and in equal measure. This result has led many scholars to ignore the Cribratio, and on the whole, the work does not offer a satisfactory solution for dialogue with Islam in religious and political terms. It is therefore not surprising that Pope Pius II hardly referred to the work of his cardinal when he was writing his politically motivated letter to the Turkish Sultan Mehmed II.

Yet, from the perspective of Christian theology, Cribratio clearly shows a deepened awareness of an underlying problem. The main difficulty for any Christian interpreter is the ambivalence of Islam, which displays both pro- and anti-Christian sides at the same time, as it is grounded in biblical transmissions on the one hand, but on the other hand categorically rejects the most important elements of the Christian faith: the notions of incarnation and divine trinity.

In this respect, an interesting development can be witnessed in Cusanus's writings. He ignores the anti-Christian side of Islam in De pace fidei, and presents it instead as a misunderstanding. Then, in his letter to John of Segovia, he implies that he is aware of the ambivalence (visible in his remark about the hermeneutic of the Quran), and finally he discusses it extensively in Cribratio Alkorani. It is clear that the uniformity of his interpretation of Islam and the Qur'an suffers from this very ambivalence. However, according to Cusanus's insight, the Janus face of Islam no longer allows for a uniform interpretation from a Christian point of view.

$30 \quad$ h VIII, n. 16. 